24. CHANCE, A. (2016) American Perspectives on the Belt and Road Initiative. Sources of Concern and Possibilities for Cooperation. Institute for China-America Studies. [Online]. Available from: http://chinaus-icas.org/materials/american-perspectives-belt-road-initiative [Accessed: 24th December 2017].

25. Approved Projects. Asian Infrastructure Investment Bank. (2017). [Online]. Available from: https://www.aiib.org/en/projects/approved/index.html [Accessed: 3d December 2017].

Надійшла до редколегії 10.11.2017 Kyiv.

Makar Taran, Ph.D., Associate Professor, Taras Shevchenko National University of

\title{
CHINA`S «ONE BELT - ONE ROAD» INITIATIVE AND STRATEGIC CHALLENGES TO THE USA
}

\begin{abstract}
At first glance the basis of the Initiative "One Belt - One Road" voiced by Chinese leader Xi Jinping is composed of geo-economics' vectors. Cooperation within the framework of the two silk routes will be complemented by social and political dynamics. Although the initiative encompasses three continents: Asia, Africa and Europe, its development is of global significance and can be a fundamental factor of changes in the world order, where the influence of the US and the West can be called system-forming. The author of the article tries to prove that the positive development of the Initiative may become a paradigm of world development that is not rather competitive but in many ways complementary with the Western one. Implementing the Initiative China, by means of this project, can prove the productivity of its own values of progress. The visions of US Global Strategy and the Grand China Strategy under D. Trump's administration remain uncertain. The isolationist and protectionist values of the American president can further undermine the credibility and effectiveness of the international institutions, projects and programs under the auspices by the United States. Washington will be forced to build somehow a concrete model of approach to the Initiative, as it affects the regions and countries that are sensitive to American interests. Moreover the Initiative shapes a soft alternative source of financial and investment assistance and is aimed at creating fundamentally new mechanisms and formats of international cooperation.
\end{abstract}

Key words: One Belt - One Road Initiative; USA and world order; China, USA and global governance; foreign policy of China; D. Trump`s foreign policy; global development.

\section{УДК 94 (5)}

http://doi.org/10.17721/2521-1706.2018.04.151-160

Gunay Feyziyeva,

Ph.D (international relations)

Institute of the Caucasus Studies, ANAS, Baku, Republic of Azerbaijan

\section{AZERBAIJAN IN THE SOUTH CAUCASUS POLICY OF GREAT POWERS}

\begin{abstract}
With its geopolitical position, natural resources, economic potential and other superior features, Azerbaijan is an important country in the South Caucasus. One of the main factors that have a positive impact on the geopolitical value of Azerbaijan and its relations with foreign countries is its significant geopolitical and geographical location. The position of Azerbaijan at the intersection of major trade routes along with the emerging East-West and North-South transport and energy corridors provides an important asset to transforming the country into an energy and infrastructure hub. Given the dynamic socio-economic development achieved over the last decade and future development potential, the Republic of Azerbaijan is considered to be geopolitically the most important and promising country in the region. Its
\end{abstract}


geopolitical character sets the country's dynamic development, its place and role in the international arena, and the value of bilateral and multilateral partnerships. The implementation of the new oil strategy and transnational energy-transport and communication projects laid down by President Heydar Aliyev in 1994 has turned Azerbaijan into an attractive partner for the world's leading states and companies. The fulfillment of the Southern Gas Corridor project will add new successes to "Contract of the Century" and to Baku-Tbilisi-Ceyhan pipeline project created on the basis thereof. Given the abovementioned factors, the regional and international powers are naturally interested in cooperation with Azerbaijan.

Key words: Azerbaijan, politics, energy, EU, USA, oil contracts

In the early 20th century, Baku was producing more than half of the world's oil. During the Second World War, Baku and its oil played crucial role in prevention the occupation of the whole Soviet Union by Nazi Germany [11, p. 5]. The rich natural resources of Azerbaijan not only open prospects for the country's prosperity and national welfare, but also constitute a valuable asset, strengthening national security, political independence and sovereignty [15, p. 13].

The most important reason for interest in the region is geostrategic position of the South Caucasus, "heart of Eurasia", is the central point of the Great Silk Way, the commercial roads that connect the Far East and Central Asia with Europe, and the natural energy resources.

Historically, the South Caucasus has served as a trade corridor and arena for competition between the Russian, Turkish, and Iranian empires; while trade today is often conducted by sea - partly due to dilapidated Caucasian infrastructure - South Caucasus states have not forgotten their role as a battleground for larger powers [4, p. 8]. While they were not independent until the early 1990s, they have spent the last two decades establishing themselves as states, and are more concerned with internal security and territorial and sovereignty disputes than with broader regional struggles. Their relationships with the US derive from very different factors - geostrategic situation, economic ties, diaspora communities, free market concerns, energy supply lines, and competition with Russia. The US has three primary geopolitical objectives in the Caucasus: security and stability, democratization, and economic access, to both the region's underutilized natural resources and the nascent infrastructure corridor for transporting Central Asian products west while avoiding Iran and Russia.

Caspian Basin resources make it influential in energy transportation and attractive for European states that wish to diversify their energy sources away from Russia. Baku's geostrategic position and increasingly-accessible resources have provided an opportunity for Europe and the US. Besides the operation and transportation of Caspian energy resources, the fact that the strategic location of the region and is the gateway to Central Asia, makes the South Caucasus important for the United States. In addition to its large population and GDP by South Caucasus standards - $\$ 9$ million and $\$ 90$ billion, respectively - Azerbaijan provides Western-friendly direct route from Central Asia to Europe and natural resources [9, p. 70]. As a result of Azerbaijan's openness to international investments, dozens of large energy companies such as BP, Exxon, Chevron, Statoil, Lukoil, NICO, TPAO and Total participate in production sharing agreements such as the Azeri-Chirag-Gunashli (ACG), a complex of oil fields, and Shah Deniz, Azerbaijan's largest gas field. Foreign companies, with BP in the lead, have also invested in oil and gas transit infrastructure such as the Baku-Tbilisi-Ceyhan (BTC) oil pipeline, the South Caucasus Pipeline (SCP, also known as the Baku-Tbilisi-Erzurum gas pipeline), TAP and TANAP [1, p. 13]. 
The vacuum created by the collapse of the Soviet energy and economic systems was sometimes filled by the growing European market. Even though demands of that market were primarily aimed towards Russia, it also left open the possibility of integration of the South Caucasus countries, especially Azerbaijan as an energy producing country [14, p. $1]$.

Despite the fact that presently alternative and renewable energy production, renewal of nuclear energy production, and implementation of various energy-saving programs in Europe gaining topicality, oil and gas still dominate Europe's energy supply. Experts' research has shown that in the near future Europe's rejection of oil and gas does not seem real. In this regard, Azerbaijan as a reliable partner plays important role in ensuring Europe's energy security [5].

The South Caucasus is considered to be the main doorway to the energy-rich Caspian basin for energy security of the European Union and for other Western actors in the region. The EU's energy security strategy considers Caspian hydrocarbons as a means to diversify its energy supplies and the South Caucasus as a strategic transit route connecting Caspian energy resources with European markets [1, p. 5]. The development of the oil sector of Azerbaijan, including the construction of oil and gas pipelines and other relevant infrastructure, already contributes to the development of the economy of Azerbaijan and generates additional incentives for regional and global cooperation. This cooperation, resulting in the successful implementation of regional infrastructure projects such as Baku-Supsa, Baku-Novorossiysk, Baku-Tbilisi-Ceyhan export oil pipelines and South Caucasus gas pipeline has increased the importance of the South Caucasus region, contributed to European and global energy security and laid foundation for the exploitation of new, vital energy sources for Europe [15, p. 19]. The EU signed a memorandum of mutual understanding and strategic partnership in the energy sector with Azerbaijan in 2006. Furthermore, Azerbaijan is one of the main energy producing and transporting countries of the Caspian region, and it has often expressed its readiness to fulfill an important role in implementing the EU's energy security strategy. In 20062007, Azerbaijan became a country with one of the fastest growing economies, which is tied with an increase in its energy resources and the price of crude oil [14, p. 6].

One of the most important directions of the multilateral and balanced foreign policy of the Republic of Azerbaijan, which is very sensitive and complicated geographically, is the establishment and development of relations with the world power centers and advanced states. In this regard, relations between Azerbaijan and the United States are of particular importance. Azerbaijan gives great importance to relations with the United States, which is the world's largest economic and political power.

Since gaining independence, Azerbaijan's foreign policy has been predicated around two primary objectives: regaining control of Nagorno Karabakh and defending the state against Russia and Iran. Azerbaijan has formed partnership with Turkey and the US, building off ethnic and economic ties with the former and strategic concerns with the latter in its campaign for territorial integrity. As the US has sought to expand its influence in the South Caucasus and support stability in the region, Washington's and Baku's interests have steadily converged over a set of shared concerns [9, p. 71].

Diplomatic relations between Azerbaijan and the United States were established in 1992. The two countries work together to promote European energy security, expand trade and investment, and combat terrorism and transnational threats. The United States has promoted peace, democracy, and diversification of the economy since independence 
in Azerbaijan. The United States supports efforts to peacefully resolve the NagornoKarabakh conflict and promote regional stability, peace, and prosperity [19].

Trade Relations Agreement and bilateral Investment Agreement have been signed between the United States and Azerbaijan. The United States has long supported Azerbaijan's efforts to develop and export its energy resources to Western markets, and crude oil is its largest import from Azerbaijan. U.S. companies are involved in offshore oil development projects in Azerbaijan, export aircraft and heavy machinery to Azerbaijan, and have been exploring emerging investment opportunities in telecommunications and other fields [19].

The government of Azerbaijan had the task of attracting U.S. oil companies in order to establish the U.S. national interests in the region and get the Armenian lobby balanced in Congress [11, p. 19]. After signing of the oil contracts, Armenian lobby's influence in the US policy in the region and in Azerbaijan began to shake and lose its position [17, p. 357].

US-Azerbaijan ties are based largely on common geopolitical need. While America has occasionally emphasized ideological objectives - most notably in the immediate postSoviet period, when Washington emphasized growing free markets and democratizing the region - a common concerned over regional stability and energy security have been the key aspects of the US-Azerbaijani relationship. Azerbaijan does see the America primarily as an extra-regional source of diplomatic support and weapons supplier, and as a source of investment in infrastructure and economic growth.

Energy and security issues are the major dimensions of the bilateral relationship between Azerbaijan and the U.S. US President George W. Bush explicitly called the US "dependent on oil" in its 2006 Nation Speech. This dependence is not only for America, but for all developed and rapidly developing countries. But the United States is clearly the world's largest energy consumer. Daily petroleum consumption in the USA is about 19 million as of 2010, which is below 14 million in the whole of the European Union. Although the US itself is one of the largest oil producers, it is also the largest oil importer in the world, with about 10 million barrels of oil imported daily, due to the high energy demand. The US is also the world leader in natural gas consumption and imports. In this regard, it is quite natural that one of the most important strategic issues of the United States is energy. After the 1973 Oil Crisis, the US has been struggling to get rid of its dependence on energy. The fact that world oil resources will be consumed in limited and long term, improvements related to global warming as well, are leading the US in search of different energy sources. As seen in recent years, with the increase in oil prices, more serious steps have been taken to diversify energy sources. In this context, there is a shift towards renewable energy sources in the US, yet limited [20, p. 17-18]. President Obama, in his speech on March 30 2011, also issued a plan for a safer energy future, emphasizing that they are aware of the dangers of being dependent on oil and that it must change now [17].

Signing of the "Contract of the Century" by consortium of international oil Companies led by Amoco and BP in September 1994, build this strategic partnership. Oil has the most important place in the US foreign policy toward the region. The US attaches great importance to both the economic and political aspects of operating the region's rich oil and natural gas resources and delivering them to the Western markets in a stable and safe manner. The aim of the US diversification policy is to reduce energy dependence on a specific region, to eliminate possibility for political transformation in the oil regions and the resulting global economic crisis. With the "Deal of the Century" for the first time 
giving Western firms a stake in Azerbaijan's oil and natural gas wealth, President Aliyev accomplished his first goal of linking the US and Europe to his state's political security [13, p. 11]. Ownership was divided among international firms with the technical expertise to extract Azerbaijan's oil and natural gas, with British Petroleum owning the largest share and Chevron, Exxon, and Norway's Statoil also holding significant portions. Russia's Lukoil was also given partial ownership, allegedly to provide Moscow with a stake and guaranteed payoff $[9$, p. 72$]$.

Contract of the century was a bigger issue than a business deal. It was a decision about which way the country chooses, a closer relationship with a wider world and a brighter future. US Presidents from Bill Clinton to Barack Obama have supported that historic deal and the project was reinforced with the ground breaking on the Southern Gas Corridor 20 years later. In his letter to Heydar Aliyev on September 20, Bill Clinton said that Azerbaijan's oil production along with the resolution of the protracted conflict in and around the Nagorno-Karabakh region, will bring stability, economic development and prosperity to the people of Azerbaijan, will be a decisive step towards the mighty economic future [10, p. 46]. The Southern Gas Corridor is one of the world's major infrastructure projects which diversifies Europe's energy sources and adds to the continent's energy security [4, p. 623].

US State Department Special Envoy and Coordinator for International Energy Affairs Amos J. Hochstein at a press conference in Baku said: "We discussed the political changes in Europe and US with the President of Azerbaijan. The United States will continue its efforts towards the realization of the Southern Gas Corridor. It is important for Azerbaijan, but also one of the energy and political security projects in Europe. The United States considers this project as a strategic project as BTC and feels the same". He noted that Azerbaijan and the United States are not just close friends, but also have strategic partnership relations: "These relations cover many areas" [3].

From the standpoint of U.S. policy, the significance of Azerbaijan's oil and gas reserves far exceeded their value as an energy resource and potential as an engine for economic development. According to this vision, Azerbaijani hydrocarbons would generate much-needed revenues for the country's reconstruction with multiplier effects rippling beyond its borders.

U.S. President Donald Trump, in his letter to President Ilham Aliyev in May 2017, noted: "Azerbaijan is a valued partner of the United States. Together, we are working to enhance global security through our joint counterterrorism efforts. We stand with the people of Azerbaijan and are committed to strengthening our relationship through dialogue on security, economic cooperation, and democratic principles" [8].

Azerbaijani President Ilham Aliyev in his speech at a meeting of the Cabinet of Ministers dedicated to results of socio-economic development in the first half of 2017 and objectives for the future said that the relations between Azerbaijan and the US are entering a new stage. He added: "The letter by US President Mr. Trump addressed to me raises the significance of the Caspian Oil and Gas Exhibition and Conference and at the same time is the US another support for successful energy projects being implemented by Azerbaijan" [6].

Luke Coffey, a Director at Douglas and Sarah Allison Center for Foreign Policy at the Heritage Foundation, as well as Research Advisor at Caspian Policy Center, in his article headlined "US - Azerbaijan Relations: Challenges and Perspectives", published on August 28, 2017, wrote: "Closer cooperation and partnership between the two countries would benefit both. The Trump Administration should take steps to improve 
relations with Baku. Azerbaijan sits at a crucial geographical and cultural crossroads linking Europe and Asia. Baku, the capital of Azerbaijan, is home to the Caspian's largest port and serves as the transportation hub for goods shipped between Europe and Central Asia. Ever since the first oil well was drilled just outside Baku in 1846, the city has been vital to the region's oil and gas industry. For Europe, Azerbaijan provides a significant oil and gas alternative to Russia. This improves Europe's security and by association the security of the U.S." [17].

On September 14 at the Heydar Aliyev Center was held ceremony on the joint development of the Azeri, Chirag and Gunashli fields in the Azerbaijani sector of the Caspian Sea and signing of amended and restated Production Sharing Agreement. The Azerbaijan Government and the State Oil Company of the Republic of Azerbaijan (SOCAR), together with BP, Chevron, INPEX, Statoil, ExxonMobil, TP, ITOCHU and ONGC Videsh signed the amended and restated agreement on the joint development and production sharing for the Azeri, Chirag fields and the Deep Water Portion of the Gunashli Field in the Azerbaijan Sector of the Caspian Sea.

President Ilham Aliyev in his speech said: "Today is a very remarkable and historic day in our country's life. A new era in the development of the Azeri-Chirag-Gunashli oil field begins. I sincerely welcome all the foreign guests to join us in this historic ceremony. Their participation in this event once again reflects the importance of today's event. The contract to be signed today is of great importance for our country. The development of the Azeri-Chirag-Gunashli oil field is extended until 2050. The new contract will be even more favorable for Azerbaijan, although the contract signed in 1994 provided our interests. In the terms of 23 years, the contract was very successful. During these years 436 million tons of oil have been extracted from Azeri-Chirag-Gunashli. I remember well that when the contract was signed in 1994, estimated reserves were determined 511 million tons. However, today's information shows that there are still about 500 million tons of oil reserves in the Azeri-Chirag-Gunashli. I am sure that this figure will increase even further during the contract execution. Today, our country is known as a strong country in the world. Today, our international relations are very broad. Azerbaijan is a country that has a very high and positive reputation in the international arena. It is no coincidence that several years ago, 155 countries chose Azerbaijan as a non-permanent member of the UN Security Council, and this was a sign of the sympathy, respect, and support of the international community. We have a great deal of currency reserves, the economy is developing dynamically, very important steps have been taken in the direction of economic diversification, reduction of dependence on oil and gas factor, and there are no political, economic, or any other obstacles or problems for the further development of our country. Our country has great potential. Over the past few years, we have strengthened this potential and the "Contract of the Century" has a special role in the development of this potential" [16].

After signing a contract for the development of the Azeri-Chirag-Guneshli (ACG) field block until 2050 in Baku, the US Ambassador to Azerbaijan, Robert Cekuta has announced the position of America on the Azeri-Chirag-Gunashli Treaty: "The United States welcomes the extension of the Production Sharing Agreement for the Azeri, Chirag and Gunashli (ACG) projects. This is a great day for Azerbaijan and its partners, which develops offshore ACG oil fields, including the United States". According to him, the signing of the Production Sharing Agreement (PSA), which was signed in 1994 and called the "Contract of the Century", and signing of the current agreement is equally important. "The ACG PSA, which has developed Azeri, Chirag and Gunashli oil fields 
on the sea, and later the formation of Azerbaijan International Operating Company, are a key stages in the international development of oil and gas, including international energy security and a great success for Azerbaijan". He noted that the United States support the development of oil and gas reserves as a key factor in promoting economic prosperity and global energy security and their safe supply to European and other markets, and the development of oil and gas resources in Azerbaijan and the Caspian Sea Basin from the beginning of the 1990. "The importance of the development of these hydrocarbon reserves and the role that they play in the international security arena are still recognized and emphasized by the United States. This reality is clearly demonstrated in a letter issued by President Tramp on May 28, in which he expressed his best wishes on the 24th International Caspian Oil and Gas Exhibition and Conference, and in a statement by Secretary of State Rex Tillerson in Advisory Board held in February on support the Southern Gas Corridor by the United States" [2]. The South Caucasus has long been seen as a battlefield for global geopolitical powers. At this moment, the region is actively involved in the interests of the United States, Russia and Iran. Despite the fact that the first two states clearly and broadly misinterpreted this, Tehran is choosing a big secret event. One of the main arguments of Iran is to bring extreme religious views to the political arena. It has been trying to apply the method in the South Caucasus it has tried in the Near and Middle East for years [18].

Implementation of the oil strategy, signing of oil contracts with international companies, US companies as well, created essential conditions for future economic development and progress of the Republic of Azerbaijan. The Contract of the Century gave Azerbaijan an opportunity to pursue a balanced foreign policy, which will be a major foreign policy orientation followed by actions of the government of Azerbaijan [11, p. 19].

Azerbaijan is at the center of the energy revolution as of today. With the development of the Shah Deniz II field, a 3,500 kilometer and 45 billion \$ worth Southern Gas Corridor has emerged and will be transmitted to Italy via the South Caucasus Pipeline (SCP), the Trans-Anatolian Pipeline (TANAP) and the Trans-Adriatic Pipeline and the dependence of Europe on Russian resources will be reduced and supply diversification for Europe will be ensured. The corridor will make Azerbaijan a supply and transit country with a potential of 31 billion cubic meters.

\section{Sources}

1. Alieva L. Energy security in the South Caucasus: views from the region. Cascade [Electronic Resource]. - Mode of Access: http://www.cascade-caucasus.eu/wp-content/uploads/2015/12/CASCADED8.3-Working-paper-Energy-Security.pdf [last access: August 4, 2017]. - Title from the Screen.

2. Amerikanın Sesi. ABŞ Azərbaycanın dünya enerji təhlükəsizliyində əsas rolunu dəstəkləməkdə davam edir [Electronic Resource]. - Mode of Access: https://www.amerikaninsesi.org/a/enerji/4028420.html [last access: November 2, 2017]. - Title from the Screen.

3. Amos Hochstein interview [Electronic Resource] - Mode of Access: https://apa.az/xarici_siyaset/dovlet-departamentinin-elcisi-abs-cenub-qaz-dehlizinin-reallasmasi-ucunseylerini-davam-etdirecek.html [last access: November 15, 2017]. - Title from the Screen.

4. Azerbaijan. Foreign Relations Department of the President of the Republic of Azerbaijan. 25 Years of Independent Azerbaijan through the Eyes of Ambassadors (Collection of Articles). Baku: "BEST-TMS" LLC, 2016. - 645 p.

5. Avropa İttifaqının enerji təhlükəsizliyinin təmin edilməsində Azərbaycanın rolu artır [Electronic Resource]. - Mode of Access: http://www.azerbaijan-news.az/index.php?mod=3\&id=54792 [last access: October 12, 2017]. - Title from the Screen. 
6. President Aliyev: Azerbaijan-U.S. relations entering new stage [Electronic Resource]. - Mode of Access: https://www.azernews.az/nation/116126.html [last access: October 16, 2017]. - Title from the Screen.

7. US - Azerbaijan Relations: Challenges and Perspectives [Electronic Resource]. - Mode of Access: http://www.caspianpolicy.org/news/us-azerbaijan-relations-challenges-and-perspectives [last access: October 11, 2017]. - Title from the Screen.

8. Consulate General of the Republic of Azerbaijan in Los Angeles. Azerbaijan-US Relations [Electronic Resource]. - Mode of Access: http://www.azconsulatela.org/Azerbaijan/Azerbaijan-USRelations [last access: November 17, 2017]. - Title from the Screen.

9. Cordesman A.H. U.S. and Iranian Strategic Competition: Turkey and the South Caucasus. CSIS | Center for strategic and international studies. Burke Chair in Strategy. [Electronic Resource]. Mode of Access: https://csis-prod.s3.amazonaws.com/s3fspublic/legacy_files/files/publication/130206_turk_casp_chap9.pdf [last access: October 12, 2017]. Title from the Screen.

10. Oliyev H.Ә. Azərbaycan nefti dünya siyasətində. 4th Ed. /H. Oliyev. - Baku: Azərbaycan nəşriyyat1, 1997. $-78 \mathrm{p}$.

11. Ibrahimov R. Energy and Azerbaijan: History, Strategy and Cooperation /R.Ibrahimov. - Baku: SAM Center for Strategic Studies, 2013. - 115 p.

12. Məmmedov F. Azərbaycan Respublikasının Xarici Siyasətinin Đsas İstiqamətləri (1991-2016) /F. Məmmedov, C. Vəliyev, A.Məmmedov. - Baku: "Poliart" MMC, 2017. - 899 p.

13. Nichol J. Azerbaijan: Recent Developments and U.S. Interests. Congressional Research Service [Electronic Resource]. - Mode of Access: https://fas.org/sgp/crs/row/97-522.pdf [last access: November 15, 2017]. - Title from the Screen.

14. Patatraia T. Energy transit and security imbalance in South Caucasus: The road between Russia and the European Union. Heinrich Böll Stiftung-The Green Political Foundation [Electronic Resource]. Mode of Access: http://ge.boell.org/sites/default/files/uploads/2015/03/energy_eng-final_1.pdf [last access: October 25, 2017]. - Title from the Screen.

15. Petersan A. Azerbaijan in Global Politics: Crafting Foreign Policy /A.Petersan, F.Ismailzade. Baku: Chashioglu Publishing House, 2009. - 372 p.

16. Ilham Aliyev attended signing ceremony of new agreement on Azeri-Chirag-Gunashli oilfields [Electronic Resource]. - Mode of Access: http://president.az/articles/25217 [last access: October 3, 2017]. - Title from the Screen.

17. The Obama Administration's Blueprint for a Secure Energy Future [Electronic Resource]. Mode of Access: https://obamawhitehouse.archives.gov/sites/default/files/blueprint_secure_energy_future.pdf [last access: October 15, 2017]. - Title from the Screen.

18. ABD’nin Güney Kafkasya Stratejisi: Diyalog mu, Çatişma mi? [Electronic Resource]. - Mode of Access: http://politikaakademisi.org/2013/03/28/abdnin-guney-kafkasya-stratejisi-diyalog-mucatisma-mi [last access: November 15, 2017]. - Title from the Screen.

19. Relations with Azerbaijan [Electronic Resource]. - Mode of Access: https://www.state.gov/r/pa/ei/bgn/2909.htm [last access: November 15, 2017]. - Title from the Screen.

20. Yilmaz Ş. Amerika Birleşik Devletleri'nin Kafkasya Politikaları Avrasya Üçlemesi-III: Kafkaslar 1989-2009 / Ş. Yilmaz. - İstanbul: Nobel Yayınevi, 2012. - 27 p.

\section{References}

1. ALIEVA, L. et al. (2015) Energy security in the South Caucasus: views from the region. Cascade [Online]. Available from: http://www.cascade-caucasus.eu/wpcontent/uploads/2015/12/CASCADE-D8.3-Working-paper-Energy-Security.pdf [Accessed: 4th August 2017].

2. Amerikanın Sesi. (2017) ABŞ Azərbaycanın dünya enerji təhlükəsizliyində əsas rolunu dastaklamakda davam [Online]. edir Available from: https://www.amerikaninsesi.org/a/enerji/4028420.html [Accessed: 2nd November 2017].

3. Apa. (2016) Amos Hochstein interview [Online]. Available from: https://apa.az/xarici_siyaset/dovlet-departamentinin-elcisi-abs-cenub-qaz-dehlizinin-reallasmasi-ucunseylerini-davam-etdirecek.html [Accessed: $15^{\text {th }}$ November 2017].

4. Azerbaijan. Foreign Relations Department of the President of the Republic of Azerbaijan. (2016) 25 Years of Independent Azerbaijan through the Eyes of Ambassadors. Baku: "BEST-TMS" LLC. 
5. (2014) Avropa İttifaqının enerji təhlükəsizliyinin təmin edilməsində Azərbaycanın rolu artır. Azerbaijan news. [Online]. Available from: http://www.azerbaijan-news.az/index.php?mod=3\&id=54792/ [Accessed: $12^{\text {th }}$ October 2017].

6. (2017) President Aliyev: Azerbaijan-U.S. relations entering new stage. AZERNEWS. [Online]. Available from: https://www.azernews.az/nation/116126.html [Accessed: $16^{\text {th }}$ October 2017].

7. (2017) US - Azerbaijan Relations: Challenges and Perspectives. Caspian Policy Center. [Online]. Available from: http://www.caspianpolicy.org/news/us-azerbaijan-relations-challenges-andperspectives [Accessed: $11^{\text {th }}$ October 2017].

8. Consulate General of the Republic of Azerbaijan in Los Angeles (2017) Azerbaijan-US Relations [Online]. Available from: http://www.azconsulatela.org/Azerbaijan/Azerbaijan-US-Relations [Accessed: $17^{\text {th }}$ November 2017].

9. CORDESMAN, A.H. et al. (2013) U.S. and Iranian Strategic Competition: Turkey and the South Caucasus. CSIS $\mid$ Center for strategic and international studies. Burke Chair in Strategy. [Online]. Available from: https://csis-prod.s3.amazonaws.com/s3fspublic/legacy_files/files/publication/130206_turk_casp_chap9.pdf [Accessed: 12 ${ }^{\text {th }}$ October 2017].

10. ӘLIYEV, H.Ә. (1997) Azarbaycan nefti dünya siyasatində. 4th Ed. Baku: Azərbaycan nəşriyyatı.

11. IBRAHIMOV, R. (2013) Energy and Azerbaijan: History, Strategy and Cooperation. Baku: SAM Center for Strategic Studies.

12. MӘMMӘDOV, F., VӘLIYEV, C. and MӘMMӘDOV, A. (2017) Azarbaycan Respublikasinın Xarici Siyasatinin Osas İstiqamatlari (1991-2016). Baku: "Poliart" MMC.

13. NICHOL, J. (2012) Azerbaijan: Recent Developments and U.S. Interests. Congressional Research Service [Online]. Available from: https://fas.org/sgp/crs/row/97-522.pdf [Accessed: 15 ${ }^{\text {th }}$ November 2017].

14. PATARAIA, T. (2015) Energy transit and security imbalance in South Caucasus: The road between Russia and the European Union. Heinrich Böll Stiftung-The Green Political Foundation [Online]. Available from: http://ge.boell.org/sites/default/files/uploads/2015/03/energy_eng-final_1.pdf [Accessed: $25^{\text {th }}$ October 2017].

15. PETERSAN, A. And ISMAILZADE, F. (2009) Azerbaijan in Global Politics: Crafting Foreign Policy. Baku: Chashioglu Publishing House.

16. President of Azerbaijan. (2017) Ilham Aliyev attended signing ceremony of new agreement on Azeri-Chirag-Gunashli oilfields [Online]. Available from: http://president.az/articles/25217 [Accessed: 3rd October 2017].

17. The WHITE HOUSE (2011) The Obama Administration's Blueprint for a Secure Energy Future [Online]. Available from: https://obamawhitehouse.archives.gov/sites/default/files/blueprint_secure_energy_future.pdf [Accessed: $15^{\text {th }}$ October 2017].

18. (2013) ABD’nin Güney Kafkasya Stratejisi: Diyalog mu, Çatişma mi? Uluslararası Politika Akademisi. [Online]. Available from: http://politikaakademisi.org/2013/03/28/abdnin-guney-kafkasyastratejisi-diyalog-mu-catisma-mi/ [Accessed: $15^{\text {th }}$ November 2017].

19. USA DEPARTMENT OF STATE (2017) U.S. Relations with Azerbaijan [Online] Available from: https://www.state.gov/r/pa/ei/bgn/2909.htm [Accessed: $15^{\text {th }}$ November 2017].

20. YILMAZ, Ş. (2012) Amerika Birleşik Devletleri'nin Kafkasya Politikaları Avrasya ÜçlemesiIII: Kafkaslar 1989-2009. Mustafa Aydın ed., İstanbul: Nobel Yayınevi.

Надійшла до редколегії07.09.2017

Гунай Фейзиєва, кандидата історичних наук, Інститут кавказьких студій НАНА, Баку, Азербайджанська Республіка

\section{АЗЕРБАЙДЖАН В ПІВДЕННО-КАВКАЗЬКІЙ ПОЛІТИЦІ ВЕЛИКИХ ДЕРЖАВ}

Анотація. 3 геополітичною позицією, природними ресурсами, економічним потенціалом та іншими чудовими особливостями, Азербайджан є важливою країною на Південному Кавказі. Одним з головних чинників, щуо позитивно впливають на геополітичну иінність Азербайджану та його відносин із зарубіжними крайнами, є його географічне 
становище. Позиція Азербайджану на перетині основних торговельних шляхів вздовж транспортних та енергетичних коридорів Схід-Захід і Північ-Південь, які розвиваються $\epsilon$ важливим активом для перетворення краӥни в центр енергетики та інфраструктури. Враховуючи динамічний сочіально-економічний розвиток, досягнутий за останнє десятиріччя та потенціал майбутнього розвитку, Азербайджанська Республіка вважається найважливішою $і$ найперспективною країною в регіоні. Реалізація нової стратегії нафти та трансначіональних енергетичних транспортних і комунікаційних проектів, закладена президентом Гейдаром Алієвим в 1994 році, перетворила Азербайджан на привабливого партнера для провідних держав та компаній світу. Реалізація проекту «Південний газовий коридор» додасть нових успіхів у реалізацію проекту «Контракт століття» та реалізації проекту Баку-Тбілісі-Джейхан на його основі. Враховуючи всі иі фактори, не випадково регіональні та міжнародні лідери зачікавлені у співпраці з Азербайджаном.

Ключові слова: Азербайджан, політика, енергетика, ЄС, США, нафтові контракти

УДК 94 (5)

Farahile Babaeva Shukurova, Research Fellow, Department of Caucasus Policy Institute of the Caucasus Study, Azerbaijan National University Republic of Azerbaijan

\title{
THE KARABAGH CONFLICT IN THE CONTEXT OF THE UNITED STATES' GLOBAL POLICY
}

\begin{abstract}
The aim of the Minsk group of OSCE established on March 1992 was to mediate the peaceful solution of the Armenia-Azerbaijan Nagorno-Karabakh conflict: "From December 1996, the Minsk Group is co-chaired by three states - Russia, the United States and France. But unfortunately the conflict still remains unresolved. Zero progress has been reached so far in the negotiation mediated by the Minsk group. Armenia is not interested in resolution of the conflict. It tends to keep the position of neither fire, nor peace. But in the early April of 2016, as result of subversion of Armenian armed forces the tension in the contact line of troops which was followed by numerous human causalities, once more confirmed that remaining the conflict frozen might would always cause the intense war." But the international mediators for some reason wouldn't demonstrate any unequivocal position upon this case although they support the territorial integrity of Azerbaijan. It is expected that the members of the Minsk group of the OSCE, as well as global community would take precise measures to solve this problem fairly. Failure to adhere to the principle of justice would draw to crisis not only the region, but also worldwide. The reality is that, the USA, Russia and France wouldn't bring the aggressor down as a neither permanent member of the UN SC, nor as a member states. It is a painful and thought-provoking truth, but it is still the case.
\end{abstract}

Key words: conflict, USA, UN, ESCO, politics.

Armenian-Azerbaijan conflict has got deep historical root causes. This process started with the movement of Armenians to the territory of Azerbaijan occupied by Russia at the beginning of the XIX century undergone through the massive terror and genocide of Azerbaijani people in 1905-1906 and 1918-1920. Later on during the Soviet Union period on the basis of the former Azerbaijani lands current Armenian SSR was established by execution of ethnic cleaning against the Azerbaijanis who had been living 